\title{
Gastrointestinal parasites among swine bred in Edo State, Nigeria
}

\author{
*Omoruyi, Z., and Agbinone, I \\ Department of Medical Laboratory Science, School of Basic Medical Sciences, \\ University of Benin, Benin City, Nigeria \\ *Correspondence to: zainab.omoruyi@uniben.edu
}

Abstract:

Background: Swine production in Nigeria is encountering several constraints among which are diseases. This study was designed to determine the prevalence of gastrointestinal parasites of swine with respect to sex, age, location and hygiene practices in the breeding sites in three piggery farms; University of Benin Animal Farm; Osasio Farm Uselu in Egor Local Government Area (LGA), and Ojemai Farm Ekehuanwa Road, Oredo LGA, Benin City, Edo State, Nigeria.

Methods: A total of 150 pigs were sampled from the 3 piggery farms. Faecal sample (10g each) was aseptically collected from the rectum of each selected pig and processed by concentration method to microscopically identify parasites in both saline and iodine preparations. A designed pre-tested structured questionnaire was intervieweradministered to each piggery owner to collect information on husbandry practices, animal health care issues and potential risk factors associated with parasitosis. Data was analysed using SPPSS version 20 software, while odd ratios (OR) with $95 \%$ confidence intervals (CI) were calculated on each potential risk factors.

Results: Of the 150 pigs examined, $130(86.6 \%)$ were infected with five gastrointestinal parasitic agents. Strongyloides ransomi 81 (54\%) was the most frequently identified parasite, followed by Ascaris suum 68 (45.3\%), Giardia lamblia 31 (20.6\%), Entamoeba polecki $10(6.6 \%)$ and Trichuris suis 10 (6.6\%). Single and mixed infections were not significantly associated with the observed prevalence $(p>0.05)$. Similarly, the sex of pig was not significantly associated with the prevalence of parasites $(p=0.8824)$. The prevalence of parasitosis among the grower $(87.8 \%)$ was not significantly different from the adult swine $(87.5 \%)(p>0.05)$. Osasio had the highest infection rate $(90.0 \%)$ but this rate was not significantly different from the two other farms $(p>0.05)$.

Conclusion: This study confirms high prevalence of gastrointestinal parasitic infections in pigs bred in Edo State, Nigeria. It is therefore recommended that farmers improve on their biosecurity and adhere to routine de-worming regimen of pigs.

Keywords: age, gender, prevalence, gastrointestinal, parasite, swine

Copyright 2020 AJCEM Open Access. This article is licensed and distributed under the terms of the Creative Commons Attrition 4.0 International License <a rel="license" href="http://creativecommons.org/licenses/by/4.0/", which permits unrestricted use, distribution and reproduction in any medium, provided credit is given to the original author(s) and the source.

\section{Parasites gastro-intestinaux chez les porcs élevés dans l'État d'Edo, au Nigéria}

\author{
*Omoruyi, Z., et Agbinone, I \\ Département des sciences de laboratoire médical, École des sciences médicales de base, \\ Université du Bénin, Benin City, Nigéria \\ *Correspondance à: zainab.omoruyi@uniben.edu
}

\begin{abstract}
Abstrait:
Contexte: La production porcine au Nigéria rencontre plusieurs contraintes parmi lesquelles les maladies. Cette étude a été conçue pour déterminer la prévalence des parasites gastro-intestinaux des porcs en fonction du sexe, de l'âge, de l'emplacement et des pratiques d'hygiène dans les sites de reproduction de trois porcheries; Ferme
\end{abstract}


animale de I'Université du Bénin; Osasio Farm Uselu dans la région du gouvernement local d'Egor (LGA) et Ojemai Farm Ekehuanwa Road, Oredo LGA, Benin City, État d'Edo, Nigéria.

Méthodes: Au total, 150 porcs ont été échantillonnés dans les 3 fermes porcines. Un échantillon fécal (10 g chacun) a été prélevé de manière aseptique dans le rectum de chaque porc sélectionné et traité par une méthode de concentration pour identifier au microscope les parasites dans les préparations salines et d'iode. Un questionnaire structuré pré-testé conçu a été administré par un intervieweur à chaque propriétaire de porcherie pour recueillir des informations sur les pratiques d'élevage, les problèmes de santé animale et les facteurs de risque potentiels associés à la parasitose. Les données ont été analysées à l'aide du logiciel SPPSS version 20, tandis que les rapports impairs (OR) avec des intervalles de confiance (IC) à 95\% ont été calculés sur chacun des facteurs de risque potentiels.

Résultats: Sur les 150 porcs examinés, $130(86,6 \%)$ ont été infectés par cinq agents parasitaires gastrointestinaux. Strongyloides ransomi 81 (54\%) était le parasite le plus fréquemment identifié, suivi par Ascaris suum 68 (45,3\%), Giardia lamblia $31(20,6 \%)$, Entamoeba polecki $10(6,6 \%)$ et Trichuris suis $10(6,6 \%)$. Les infections simples et mixtes n'étaient pas associées de manière significative à la prévalence observée $(p>0,05)$. De même, le sexe du porc n'était pas significativement associé à la prévalence des parasites $(p=0,8824)$. La prévalence de la parasitose chez le producteur $(87,8 \%)$ n'était pas significativement différente de celle des porcs adultes $(87,5 \%)$ $(p>0,05)$. Osasio avait le taux d'infection le plus élevé $(90,0 \%)$ mais ce taux n'était pas significativement différent des deux autres fermes $(p>0,05)$.

Conclusion: Cette étude confirme la forte prévalence des infections parasitaires gastro-intestinales chez les porcs élevés dans l'État d'Edo, au Nigeria. Il est donc recommandé que les éleveurs améliorent leur biosécurité et adhèrent au régime vermifuge de routine des porcs.

Mots-clés: âge, sexe, prévalence, gastro-intestinal, parasite, porcin

\section{Introduction:}

Swine production is one of the fastest growing livestock sectors worldwide and forms an integral part of the rural economy in many parts of the world by providing additional animal protein sources for human consumption, generating employment and reducing poverty (1). Swine production has a number of advantages over other livestock sectors, which includes higher and quicker returns on investment, early maturity, short generation interval and smaller space requirements for production (2). Parasitic diseases from infection by protozoans, helminths, and some arthropods have an immense influence on the lives of humans and animals, causing variety of illnesses that could be rapidly fatal in some cases or chronic, incidental or even asymptomatic (3). The major diseases of pigs include Africa swine fever, swine influenza, parasitic and non-infectious diseases. Parasitic diseases are a major obstacle to the growth of the pig industry.

Helminthiasis in pigs is often associated with subclinical infections resulting in poor feed conversion and delayed achievement of market weight (4). The common pig parasites identified in previous studies include Strongyloides species, Ascaris species, Trichuris species, Entamoeba histolytica and Entamoeba coli $(5,6,7)$. In Nigeria, intestinal parasitism is a debilitating condition in piggery. In spite of this, helminthiasis is often neglected because of its in apparent clinical signs. This branch of livestock industry in developing countries like Nigeria is however, saddled with religious, cultural, social and environmental challenges as well as infectious diseases (5). Stunted growth and prolonged fertility are often associated with helminthiasis. This is a major setback to efficient, effective and result oriented livestock production (8). The aim of this study is to determine the prevalence of gastrointestinal parasites of swine in selected piggery in Benin City, Edo State, Nigeria.

\section{Materials and method:}

\section{Study area}

This study was carried out in three different pig farms; University of Benin Animal farm; Osasio farm, Uselu, Egor LGA, and Ojemai farm, Ekehuanwa Road, Oredo LGA, in Benin City, Edo State, Nigeria. Benin City is the capital of Edo State, located in South-south Nigeria. It has an estimated population of $1,147,188$ (9). The State relies on trading, private transport system, farming (pig, cattle and goat) from the northern part of Nigeria as one of its sources of protein.

Egor LGA has an area of $93 \mathrm{~km}^{2}$ and lies between longitude 50 34E and latitude 6을 $23 \mathrm{~N}$, with a population of 339,899 (9) and a population density of 70 people $/ \mathrm{km}^{2}$ with headquarters in Uselu town. It shares borders with Ovia Northeast in Oredo, Ovia Southwest, and Ikpoba-Okha LGAs. Oredo has an area of $249 \mathrm{~km}^{2}$ and a population of 295,818 inhabitants by the 2006 census and lies between longitude $5037 \mathrm{E}$ and $15 \underline{026 \mathrm{E}}$ and latitude $6 \underline{0}$ $19 \mathrm{~N}$ and $58^{\circ} 83 \mathrm{~N}$.

\section{Study population and ethical approval}

A total of 150 pigs were randomly 
selected, 50 from each farm. Prior to the conduct of the study, ethical approval was obtained from Ethics and Research Committee, Ministry of Health, Benin City, Edo State, and informed consent was obtained from the swine breeders.

\section{Sample collection and processing}

Faecal specimens were aseptically collected in the morning into universal containners from the rectum of piglets, growers and adult swine bred $(n=150)$ in the selected study area. The samples were properly labelled and transported to the laboratory of University of Benin Teaching Hospital, Benin City, Edo State for processing.

The faecal samples were processed using sedimentation technique (10). About $1 \mathrm{~g}$ of faecal sample was mixed in $4 \mathrm{ml} 10 \%$ formal saline, properly mixed and sieved. To the filtrate, $3 \mathrm{ml}$ of diethyl ether was added, mixed and spun at 3000rpm for 3 minutes. The supernatant was discarded and the sediment was resuspended, and examined in both saline and iodine preparations under the light micro- scope (Nikon, Tokyo, Japan) using $10 x$ and $40 x$ objectives. Eggs were identified on the basis of their morphological features as described by Soulsby (11).

\section{Statistical analysis}

The data obtained were analysed using SPSS version 20 software, and odd ratios (OR) with $95 \%$ confidence intervals $(\mathrm{Cl})$ were calculated for each potential risk factor.

\section{Results:}

The overall prevalence rate of gastrointestinal parasites in the study sites was $86.6 \%(130 / 150)$ with prevalence rate of $90 \%$ in Osasio, 85\% in Ojemai and $84 \%$ in University of Benin farm $(p=0972)$ (Table 1$)$. Five gastrointestinal parasites of medical importance were identified; Strongyloides ransomi was the predominant intestinal parasite in the study with $54 \%$ (81/150) (Table 2).

The overall mixed infection rate was $21.3 \%$ with University of Benin farm having the highest mixed infection rate (Table 3 ). Sow were

Table 1: Frequency distribution of gastrointestinal parasites in relation to location

\begin{tabular}{lccc}
\hline Location & Number examined & Number infected (\%) & $p$ value \\
\hline Uniben Farm & 50 & $42(84)$ & 0.972 \\
Ojeimai Farm & 50 & $43(85)$ \\
Osasio Farm & 50 & $45(90)$ \\
Total & 150 & $130(86.6)$
\end{tabular}

Table 2: Frequency distribution of parasites among swine in Benin City, Edo State, Nigeria

\begin{tabular}{ccc}
\hline Species & Number positive & \% Prevalence \\
\hline Strongyloides ramsoni & 81 & 54 \\
Ascaris suum & 68 & 45.3 \\
Giardia lamblia & 31 & 20.6 \\
Entamoeba polecki & 10 & 6.6 \\
Trichuris suis & 10 & 6.6
\end{tabular}


Table 3: Prevalence of single and mixed infections of gastrointestinal parasites in the three different study sites

\begin{tabular}{lllll}
\hline Site & Number examined & Single infection (\%) & Mixed infection (\%) & $p$ value \\
\hline Uniben Farm & 50 & $30(60)$ & $12(24)$ & 0.789 \\
Ojeimai Farm & 50 & $32(64)$ & $11(22)$ \\
Osasio Farm & 50 & $36(72)$ & $9(18)$ \\
Total & 150 & $98(65.3)$ & $32(21.3)$ & \\
\hline
\end{tabular}

Table 4: Distribution of gastrointestinal parasites in relation to sex of swine

\begin{tabular}{lllll}
\hline Sex & Number examined & Number infected (\%) & Odd ratio (0R) & $95 \% \mathrm{Cl}$ \\
\hline Female (sow) & 61 & $54(88.5)$ & 0.9646 & $0.6001-1.554$ \\
Male (boar) & 89 & $76(85.4)$ & & 0.8824 \\
Total & 150 & $130(86.6)$ & & \\
\hline
\end{tabular}

Table 5: Distribution of gastrointestinal parasites in relation to age of swine

\begin{tabular}{llll}
\hline Age (weeks) & Number examined & Number infected $\%)$ & $p$ value \\
\hline $1-10$ (piglet) & 45 & $38(84.4)$ & 0.875 \\
$11-20$ (grower) & 41 & $36(87.8)$ & \\
$>20$ (adult) & 64 & $56(87.5)$ & \\
Total & 150 & $130(86.6)$ & \\
\hline
\end{tabular}

more infected (88.5\%) compared to Boar $(85.4 \%)$ but the difference was not statistically significant associated $(\mathrm{OR}=0.9646,95 \% \mathrm{CI}=$ $0.6001,1.554 ; p=0.8824$ ) (Table 4). For age distribution, the growers had a higher prevalence of $87.8 \%$ compared to adult $87.5 \%$ and piglets $84.4 \%$, though the difference was not statistically significant ( $p>0.05)$ (Table 5).

\section{Discussion:}

This study confirms the reports of previous study on the prevalence of gastrointestinal parasites in swine (12), which indicates that gastrointestinal parasitic infection is one of the major challenges facing breeding pigs in Edo State. The prevalence of $86.6 \%$ reported in this study is higher than the rate of $74.8 \%$ reported in Makurdi, Benue State (13) and $79.0 \%$ in a commercial farm in Abia State, Nigeria (14). This may be attributed to poor sanitary condition, nutritional challenges and poor routine treatment in the present study. The result of this study is consistent with the reports of Okorafor et al., (12) and Tidi and Ella (5) who also reported high prevalence of similar gastrointestinal parasites in pigs in Nigeria. A higher prevalence $(91.0 \%)$ than the present findings was reported in Burkina Faso, a West African country like Nigeria (16).

The faecal examination during the study revealed the presence of five common gastrointestinal parasites of swine similar to reports that Trichuris suis, Ascaris suum, Strongyloides ransomi and Entamoeba polecki were the most prevalent parasites of swine in a research farm (12). This could be attributed to the extensive system of farm management widely practiced within the study area, lack of veterinary services, irregular deworming observed in the farms, and low income to maintain the farms. Single infection was more prevalent (65.3\%) compared to mixed infection (21.3\%), though this was not significantly different $(p=0.789)$. This is consistent with the study by 
Atawalna et al., (15) which reported that single infections were more prevalent in parts of Ghana. The possible explanation to the mixed infection might be the fact that pigs are reared extensively and also their feeding troughs are not cleaned regularly which might aid acquisition of more infective eggs of parasites from contaminated environment.

The results of this study also showed that sex and age of the swine were not significantly associated with infection $(p>0.05)$ however sow had a slightly higher prevalence $(88.52 \%)$ compared to boar $(85.4 \%)$. This finding agrees with other studies that reported higher prevalence of intestinal parasites in sow than boar in Nigeria (5) and Burkina Faso (16) but disagrees with previous studies that reported higher prevalence in boar than sow $(17,18)$. This could be due to the fact that female pigs are kept much longer for breeding purposes as compared to the male pigs, which are usually fattened and sold off (12). With regards to age, adult pigs recorded the higher prevalence though the prevalence in relation to the infection was not significant. It has been suggested that the confinement of the piglets and growers in the pens tend to reduce their chances of contact with the disease agents.

With respect to location, the prevalence of infection among the pigs in the three farms were high and although the prevalence was slightly higher in Osasio farm, this was not significantly different from the other farms. The high prevalence of infection in all the farms could be the result of common poor management system and types of husbandry practiced in the farms.

In conclusion, this study confirmed the presence of five gastrointestinal parasites that are significant threat to pigs in the study areas. Based on the possibility of transfer of some of these helminths from pigs to man, there is urgent need to develop strategies to control the parasites in pigs.

\section{Acknowledgments:}

The authors acknowledge the support of the Head of Department, Medical Laboratory Science, University of Benin and staff of Medical Microbiology Department, University of Benin Teaching Hospital in conduct of the study.

\section{References:}

1. Seid, A., and Abebaw, G. Production systems dynamism and parasitic interaction of swine in and around Holetta. Ethiopia. Ethiop Vet J. 2008; 14 (1):71 - 81 .
2. Lekule, F. P., and Kyusgaard, N.C. Improving Pig husbandry in tropical resource poor communities and its potential to reduce risk of porcine Cysticercosis. Acta Trop. 2003; 87: 111 - 117.

3. Smyth, J. D. Habitats and environments of parasites in introduction to Animal parasitology. English Universities Press Limited. 1972; 20: 72 75.

4. Borthakur, S. K., Rahmani, S., and Sama, K. Prevalence of Gastrointestinal helminthes in Pigs in Aizawl. J Vet Parasitol. 2007; 21(2): 173 - 174.

5. Tidi, S. K., and Ella, F.A. Prevalence of Gastrointestinal parasites of pigs in Jos, Plateau State, Nigeria. Nig J Parasitol. 2011; 32(1): 37 40.

6. Olaniyi, A. J. Public health implications of gastrointestinal parasites of pigs in Kwara State Nigeria. J Animal Vet Adv. 2014; 13: 783 - 785.

7. Jufare, A., Awole, N., Tadesse, F., et al. Parasites of pigs in two farms with poor husbandry practices in Bishoftu, Ethiopia. Onderstepoort J Vet Res. 2015; 821- 5 .

8. Geresu, M. A., Hailemariam, Z., Mamo, G., et al. Prevalence and associated risk factors of major gastrointestinal parasites of pig slaughtered at Addis Ababa Abattoirs Enterprise, Ethiopia. J Vet Sci Technol. 2015; 6:4

9. Ministry of Land and Survey. Edo State Ministry of Land, Survey and Town Planning. 2008; 122

10. Cheesbrough, M. District Laboratory Practice in Tropical countries part1. $2^{\text {nd }}$ eds, Cambridge University Press, Cambridge. 2009; 195 - 216.

11. Soulsby, E. J. L. Helminths, Arthropods and Protozoa of Domesticated Animals, $7^{\text {th }}$ Edition, Balliere, Tindall and Cassel, London.1982; 809.

12. Okorafor, U. P., Unigwe, C. R., Okorafor, J. C., et al. A survey of gastrointestinal parasites of pigs that arrived for slaughter at Bodija Abattoir, Ibadan, Oyo State, Nigeria. Int J Pure Appl Sci Technol. 2014; 20(2):53-57.

13. Amuta, E.U., Houmsou, R.S., Amuta, P.O., et al. Gastrointestinal parasites of swine under small scale management in Makurdi, Benue State, Nigeria. Nig J Parasitol. 2015; 36(1): 67-71

14. Ohaeri, C. C., and Okoro, C. T. Gastrointestinal parasites of pigs in a commercial farm in IsialaNgwa North, Abia State, Nigeria. Nig J Parasitol. 2012; 33(1): 63-66.

15. Atawalna, J., Attoh-kotok, V., Folitse, R. D., et al. Prevalence of gastrointestinal parasites among pigs in the Ejisu Municipality of Ghana. Schol J Agri Vet Sci. 2016; 3: 33 - 36

16. Tamboura, H. H., Banga-Mboko, H., and Maes, D., Youssao, L., Traore, A., and Bayala, B. Prevalence of common gastrointestinal nematode parasites in scavenging pigs of different ages and sexes in Eastern Centre Province, Burkina Faso. Onderstepoort J Vet Res. 2006; 73 (1): 53-60.

17. Omudu, E. A., Amura, E. U., and Tse, D. A. Intestinal Helminthes of urban pigs with notes on public health implications. J Pest Dis Vec Managt. 2006; 7: 424-429.

18. Sowemimo, O. A., Asaolu, S. O., Adegoke, F. O. et al. Epidemiological survey of gastrointestinal parasites of pigs in Ibadan, Southwest Nigeria. J Publ HIth Epidemiol. 2012; 4(10):294-298. 